\title{
24. SILICEOUS MICROFOSSIL STRATIGRAPHIC SYNTHESIS OF SITE 892, CASCADIA MARGIN ${ }^{1}$
}

\author{
Elisabeth Fourtanier ${ }^{2}$ and Jean-Pierre Caulet ${ }^{3}$
}

\begin{abstract}
Diatom and radiolarian biostratigraphic results are compiled from Holes 892A, 892D, and 892E on the Cascadia Margin. Radiolarians are useful in the upper 80 meters, whereas diatoms are useful in most of the 173-m section drilled at Site 892. There is good agreement between diatom and radiolarian stratigraphic results. Sediments at Site 892 range in age from middle Miocene to Quaternary. The stratigraphic record, however, is not continuous or in stratigraphic order as many reversals (where older sediments overlie younger sediments) and unconformities are present.

Four reversals are present in Hole 892A at $\sim 99$ meters below seafloor, 64-68 mbsf, 116-125 mbsf, and 145-164 mbsf. Seven reversals are observed in Hole 892D at $\sim 59$ mbsf, 60 mbsf, 62 mbsf, 65-71 mbsf, 77-111 mbsf, 129-139 mbsf, and 151157 mbsf. Three hiatuses/unconformities are present in Hole 892A at $21-29 \mathrm{mbsf}, 62 \mathrm{mbsf}$, and 125-145 mbsf. Six hiatuses/ unconformities are observed in Hole 892D at 38 mbsf, 58 mbsf, 61 mbsf, 72 mbsf, 123-129 mbsf, and 161 mbsf. One reversal at $\sim 38 \mathrm{mbsf}$ and one hiatus/unconformity at $\sim 40-43 \mathrm{mbsf}$ are present in Hole $892 \mathrm{E}$, which recovered only a short section of sediment.

Despite differences between Holes 892A and 892D, most of the reversals and unconformities are correlative between the two holes. Biostratigraphy confirms the presence of a fault at $\sim 50 \mathrm{mbsf}$ as inferred from the Formation MicroScanner (FMS) $\log$ and a fault zone between 62.5 and $67 \mathrm{mbsf}$ as suggested by structural evidence and a temperature anomaly. The presence of an active fault zone at $\sim 106-116 \mathrm{mbsf}$ is also supported by biostratigraphic evidence. The time intervals $6.2-7.5 \mathrm{Ma}$ and $9.0-$ 11.4 Ma, which are not represented in any of the recovered sediments, correspond to widely recognized deep-sea hiatuses in the world's oceans.
\end{abstract}

\section{INTRODUCTION}

A primary goal of Leg 146 was the investigation of fluid flow and sediment deformation within the accretionary wedge that forms the Cascadia Margin. Site 892 is located at $44^{\circ} 40^{\prime} \mathrm{N}, 125^{\circ} 7^{\prime} \mathrm{W}$, on the Oregon continental slope at 674 meters below sea level. The site was positioned on the western flank of the second ridge within the accretionary wedge to intersect both the bottom-simulating reflector (BSR) at about $73 \mathrm{mbsf}$ and a hydrologically active, landward-dipping fault ( 105 mbsf) (Shipboard Scientific Party, 1994).

Radiolarians and foraminifers were studied on board the JOIDES Resolution. A shore-based study of the diatoms was conducted after the cruise. Because of the scarcity of foraminiferal associations and an inconclusive magnetostratigraphy, only diatoms and radiolarians could be used to provide a detailed biostratigraphy of Site 892 .

This paper provides a biostratigraphic interpretation of Site 892 . integrating the results of diatom (Fourtanier, this volume) and radiolarian (Caulet, this volume) analyses. Age vs. depth curves illustrate our results and provide support for discussion about correlation between the different holes, the position and significance of the reversals, and sediment accumulation rates.

\section{METHODS}

Diatoms and radiolarians were studied from a total of about 100 samples from Holes 892A, 892D, and 892E (about one sample per

Carson, B., Westbrook, G.K., Musgrave, R.J., and Suess, E. (Eds.), 1995. Proc. ODP, Sci. Results, 146 (Pt. 1): College Station, TX (Ocean Drilling Program).

${ }^{2}$ Diatom Collection, Department of Invertebrate Zoology and Geology, Califomia Academy of Sciences, Golden Gate Park, San Francisco, CA 94118, U.S.A.

Laboratoire de Géologie, Muséum National d'Histoire Naturelle, UA 723 du CNRS, 43 rue Buffon, 75005, Paris, France. section). In many cases, diatoms and radiolarians were studied from the same samples; most core-catchers, however, were studied for radiolarians only.

The absolute ages in this paper are given according to the Cande and Kent (1992) time scale. Most North Pacific diatom datum levels (first and last occurrences of stratigraphically significant taxa) are from Koizumi and Tanimura (1985) and Barron (1992a) for the ages younger than $6.0 \mathrm{Ma}$ and from Barron and Gladenkov (in press) for the ages older than 6.0 Ma. North Pacific radiolarian datum levels are after Morley and Nigrini (in press).

\section{RESULTS}

Age-diagnostic diatoms are present in most samples examined from the 173-meter section drilled at Site 892. Radiolarians are useful only in the top 80 meters; as a result, ages below 80 mbsf are based solely on diatom biostratigraphy. The reader is referred to Fourtanier (this volume) and Caulet (this volume) for detailed description of the diatom and radiolarian assemblages and biostratigraphic interpretation of Site 892.

Diatom and radiolarian taxa used to establish the stratigraphy of Site 892 are listed in Tables 1 and 2, respectively, along with estimates of the absolute age of their first and last occurrences in the North Pacific.

Results are summarized in Table 3 that gives the diatom-based age and the radiolarian-based age for each sample (or group of samples) from Holes 892A, 892D, and 892E. Sediments recovered from Site 892 are Quaternary, Pliocene, and Miocene in age; however, because of reversals and hiatuses, they do not form a continuous sequence and are not in stratigraphic order.

Figure 1 displays depth vs. age curves for Holes 892A and 892D, showing diatom and radiolarian age constraints as well as sedimentation rates. The position of stratigraphic reversals (or older sediments 
Table 1. North Pacific diatom datum levels used to date Site 892.

\begin{tabular}{|c|c|c|c|c|}
\hline & Taxon & $\begin{array}{l}\text { Age } \\
(\mathrm{Ma})\end{array}$ & Area & Source \\
\hline LO & Simonseniella curvirostris & 0.3 & NP & 4 \\
\hline LO & Nitzschia reinholdii & $0.50-0.55$ & NP & 4 \\
\hline FO & Simonseniella curvirostris & 1.6 & NP & 4 \\
\hline LO & Thalassiosira antiqua & 1.8 & NP & 1 \\
\hline FO & Pseudoeunotia doliolus & 2.0 & NP & 4 \\
\hline LO & Neodenticula koizumii & 2.0 & NP & 3 \\
\hline LO & Thalassiosira convexa & 2.4 & NP & 4 \\
\hline LCO & Neodenticula kamtschatica & $2.63-2.7$ & NP & 4 \\
\hline FO & Neodenticula seminae & 2.7 & NP & 3 \\
\hline FO & $\begin{array}{l}\text { Rhizosolenia praebergonii } \mathrm{v} \text {. } \\
\text { praebergonii }\end{array}$ & 3.1 & EQP & 1 \\
\hline FO & Stephanopyxis dimorpha & 3.7 & NP & 2 \\
\hline FO & Neodenticula koizumii & $3.51-3.85$ & NP & 4 \\
\hline LO & Thalassiosira nativa & 5.2 & $\mathrm{CA}$ & 2 \\
\hline FO & Neodenticula kamtschatica & 5.4 & $\mathrm{CA}$ & 1 \\
\hline FO & Thalassiosira oestrupii & $5.4,5.7$ & EQP & 1,4 \\
\hline LO & Thalassiosira miocenica & 5.7 & $\mathrm{NP}$ & 5 \\
\hline LO & Nitzschia miocenica & 6.0 & EQP & 1 \\
\hline FO & Thalassiosira miocenica & 6.2 & $\mathrm{NP}$ & 5 \\
\hline LO & Synedra jouseana & $6.5-6.6$ & NP & 5 \\
\hline LCO & Rouxia californica & 6.6 & $\mathrm{CA}$ & 3 \\
\hline FO & Nitzschia reinholdii & $6.9,7.2-7.3$ & $\mathrm{CA}$ & 1,5 \\
\hline FO & Neodenticula kamtschatica & $7.1-7.2$ & NP & 5 \\
\hline LCO & Thalassionema schraderi & $7.4-7.5$ & NP & 5 \\
\hline LO & Denticulopsis katayamae & $8.1-8.2$ & NP & 5 \\
\hline LO & Thalassiosira minutissima & $8.2-8.3$ & NP & 5 \\
\hline LO & Nitzschia praereinholdii & 8.3 & NP & 5 \\
\hline FO & Thalassiosira antiqua & 8.3 & $\mathrm{CA}$ & 1 \\
\hline LCO & Denticulopsis hustedtii & 8.4 & NP & 5 \\
\hline FO & Thalassionema schraderi & $8.6-8.5$ & CA & 1 \\
\hline LO & Rhizosolenia miocenica & 9.0 & NP & 1 \\
\hline FO & Thalassionema schraderi & $9.3,9.4$ & NP & 5 \\
\hline FO & Denticulopsis katayamae & $9.4,9.1$ & NP & 5 \\
\hline FO & Thalassiosira minutissima & $9.4,9.1$ & NP & 5 \\
\hline LO & Rhizosolenia praebarboi & 9.5 & NP & 5 \\
\hline LCO & Denticulopsis praedimorpha & 11.4 & NP & 5 \\
\hline FO & Nitzschia praereinholdii & $11.8-11.7$ & NP & 1 \\
\hline FO & Simonseniella barboi & $12.0-12.4$ & NP & 5 \\
\hline FO & Denticulopsis praedimorpha & 12.8 & NP & 5 \\
\hline
\end{tabular}

Notes: Absolute ages according to the Cande and Kent (1992) time scale. LO = last occurrence, $\mathrm{LCO}=$ last common occurrence, $\mathrm{FO}=$ first occurrence. 1 = Barron (1992a); 2 = Barron (1992b); 3 = Koizumi (1992); 4 = Koizumi and Tanimura (1985); 5 = Barron and Gladenkov (in press). NP = North Pacific; $\mathrm{EQP}=$ equatorial Pacific; $\mathrm{CA}=$ California.

overlying younger sediments) and hiatuses (or unconformities) are shown, and a correlation between the two holes is inferred.

\section{Hole 892A}

Cores 146-892A-1X to $3 \mathrm{X}$ represent a sequence of Pleistocene to upper Pliocene sediments ( 0.9 to $2.7 \mathrm{Ma})$. The sequence is interrupted between Cores 146-892A-3X and $4 \mathrm{X}$ by a hiatus of about 3 m.y. in duration. Sediments in Core 146-892A-4X to upper Core 146$892 \mathrm{~A}-7 \mathrm{X}$ are late Miocene in age and range from $6 \mathrm{Ma}$ to $8.6 \mathrm{Ma}$. A reversal is observed in Core 146-892A-7X (at 48.99 to $50.43 \mathrm{mbsf}$ ) with the return of Pliocene sediments in Cores 146-892A-7X and 8X. Another reversal is observed between Cores 146-892A-8X and 9X (at 64.70 to $67.92 \mathrm{mbsf}$ ) between uppermost Miocene sediments (bottom of Core 146-892A-8X) and Pliocene sediments (Core 146-892A$9 \mathrm{X})$. In Cores 146-892A-9X to $15 \mathrm{X}$, the Pliocene sequence ranges in age from about $2.8 \mathrm{Ma}$ to about $5.4 \mathrm{Ma}$. Below $100 \mathrm{mbsf}$, recovery is not very good and some intervals lack biostratigraphic markers. However, reversals are observed between Core 146-892A-15X (lower Pliocene) and Core 146-892A-16X (upper Pliocene; 116.42 to $125.64 \mathrm{mbsf}$ ), and between Core 146-892A-18X (upper Miocene) and Core 146-892A-20X (upper Pliocene; 145.45 to $163.69 \mathrm{mbsf}$ ).

\section{Hole 892D}

Cores 146-892D-1X to $4 \mathrm{X}$ represent a sequence of Pleistocene to upper Pliocene sediments ( 0.9 to $2.6 \mathrm{Ma}$ ), continuing with upper Mi-
Table 2. North Pacific radiolarian datum levels used to date Site 892.

\begin{tabular}{llc}
\hline & \multicolumn{1}{c}{ Taxon } & Age \\
& & (Ma) \\
\hline LO & Lychnocanoma nipponica sakai & 0.05 \\
LO & Stylacontarium acquilonium & 0.4 \\
LO & Stylatractus universus & 0.55 \\
FO & Lamprocyrtis nigriniae & $0.8-1.2$ \\
LO & Lamprocyrtis neoheteroporos & 0.9 \\
LO & Eucyrtidium matuyamai & 1 \\
LO & Lamprocyrtis heteroporos & 1.7 \\
LO & Sphaeropyle robusta & $1.5-1.7$ \\
FO & Eucyrtidium matuyamai & 2 \\
FO & Lamprocyrtis neoheteroporos & $2.6-2.8$ \\
FO & Cycladophora davisiana & 2.9 \\
FO & Sphaeropyle langii & 4.8 \\
LO & Dictyophimus splendens & 4.8 \\
LO & Theocorys redondoensis & 4.9 \\
LO & Stichocorys peregrina & 6.4 \\
FO & Lamprocyrtis heteroporos & 6.6 \\
LO & Stichocorys delmontensis & 6.8 \\
Transition & S. delmontensis-S. peregrina & 7.5 \\
FO & Stylacontarium acquilonium & 7.7 \\
LO & Cyrtocapsella japonica & 10 \\
FO & Dictyophimus splendens & 15.5 \\
FO & Theocorys redondoensis & 16.25 \\
& &
\end{tabular}

Notes: Absolute ages according to the Cande and Kent (1992) time scale. Ages of North Pacific datum levels after Morley and Nigrini (in press).

$\mathrm{FO}=$ first occurrence, $\mathrm{LO}=$ last occurrence.

ocene through middle Miocene sediments in Core 146-892D-5X to upper Core 146-892D-7X. The sequence, however, is not continuous, as the interval between 2.6 and $8.3 \mathrm{Ma}$ is missing in the upper part of Core 146-892D-5X and the interval between 9.0 and $11.4 \mathrm{Ma}$ is missing in the middle part of Core 146-892D-7X (Table 3). A reversal is present in Core 146-892D-7X (59.39 to $60.08 \mathrm{mbsf}$ ) with a return to upper Miocene sediments. The section of Hole 892D between 59 and 71 mbsf, where sediment ages alternate between Miocene and Pliocene, appears to be particularly disturbed as one unconformity (at 61.24-62.13 mbsf) and four reversals (at 59.39-60.08 mbsf, 60.0861.24 mbsf, 62.13-63.57 mbsf, and 65.15-71.13 mbsf) are observed within twelve meters. The presence of upper Pliocene sediments in Cores 146-892D-11X and $12 \mathrm{X}$ implies the existence of a reversal between Cores 146-892D-9X and 11X (73.85 to $111.46 \mathrm{mbsf}$ ). Sediments are mostly upper Pliocene in Cores 146-892D-11X to 16X, with two short Miocene intervals in Cores 146-892D-13X and 16X, and a Quaternary interval in Core 146-892D-16X (Table 3). Two more reversals are observed in Cores 146-892D-13X and 15X, at depths of 128.63 to $138.76 \mathrm{mbsf}$ and 151.27 to $157.37 \mathrm{mbsf}$, respectively.

\section{Hole 892E}

Diatoms were the only age-diagnostic microfossils in the short section cored at Hole 892E. Core 146-892E-1X is Quaternary; Cores $146-892 \mathrm{E}-3 \mathrm{H}$ and $4 \mathrm{H}$ are mostly middle late Miocene $(9.0-8.3 \mathrm{Ma})$, with younger sediments (7.3-1.8 Ma) intercalated in Core 146-892E$3 \mathrm{X}$ (Sample 146-892E-3H-6, 20-22 cm).

\section{DISCUSSION}

\section{Comparison Between Diatom and Radiolarian Ages}

Diatom and radiolarian ages agree very well in the Pliocene and Pleistocene sediments of Site 892. Furthermore, combination of the diatom and radiolarian evolutionary events considerably improves the age constraints and provides a more precise biostratigraphy than either microfossil group alone.

In the Miocene sections of Site 892, however, some discrepancies are observed between radiolarian and diatom ages. These discrepan- 
Table 3. Comparison of diatom and radiolarian ages for Site 892 .

\begin{tabular}{|c|c|c|c|c|}
\hline \multirow{2}{*}{$\begin{array}{c}\text { Core, section, } \\
\text { interval }(\mathrm{cm})\end{array}$} & \multirow{2}{*}{$\begin{array}{l}\text { Depth } \\
\text { (mbsf) }\end{array}$} & \multicolumn{3}{|c|}{ Age (Ma) } \\
\hline & & Diatoms & Radiolarians & Combined \\
\hline $\begin{array}{l}146-892 A- \\
\text { IX-1, } 128-130 \\
\text { 1X-2, 126-129 } \\
\text { 1X-3,7-9 } \\
\text { 1X, CC } \\
2 X-3,52-54 \\
2 X, C C \\
3 X-1,14-16 \text { to } 3 X-2,28-30 \\
3 X, C C \\
4 X-1,64-66 \text { to } 4 X-2,28-30 \\
4 X, C C \\
6 X-1,34-35 \text { to } 6 \text { X-2, } 93-95 \\
6 X, C C \\
7 X-1,49-52 \\
7 X-2,42-43 \text { to } 8 X-3,24-26 \\
8 X-4,104-106 \text { to } 8 X-5,38-40 \\
8 X, C C \\
9 X-1,42-45 \text { to } 11 X-1,44-46 \\
12 X-1,15-18 \\
13 X-1,14-15 \text { to } 13 X-8,91-93 \\
14 X-1,46-47 \\
15 X-1,42-44 \\
16 X-1,14-15 \\
16 X-1,33-34 \\
18 X-1,95-96 \\
20 X-1,19-20 \text { to } 20 X-1,142-144 \\
20 X-2,44-46 \text { to } 20 X-2,133-134\end{array}$ & $\begin{array}{c}1.29 \\
2.77 \\
3.04 \\
4.30 \\
13.02 \\
13.50 \\
19.14-20.78 \\
23.20 \\
29.14-29.80 \\
30.30 \\
39.34-41.43 \\
45.70 \\
48.99 \\
50.43-61.27 \\
63.49-64.33 \\
64.70 \\
67.92-78.44 \\
87.65 \\
97.14-104.36 \\
106.96 \\
116.42 \\
125.64 \\
135.33 \\
145.45 \\
163.69-164.92 \\
165.56-166.35\end{array}$ & $\begin{array}{c}1.6-0.3 \\
1.6-0.3 \\
1.8-1.6 \\
1.8-1.6 \\
2.7-2.6 \\
6.2-6.0 \\
8.6-8.3 \\
8.6-8.3 \\
3.7-2.6 \\
6.2-6.0 \\
3.7-2.6 \\
\text { Barren } \\
5.4-3.7 \\
\text { Barren } \\
5.4-3.7 ? \\
3.7-2.6 \\
\text { No markers } \\
7.3-6.6 \\
2.6-1.6 \\
5.4-2.6\end{array}$ & $\begin{array}{c}1.0-0.9 \\
1.7-1.0 \\
1.7-1.0 \\
1.7-1.0 \\
2.0-1.7 \\
2.0-1.7 \\
2.9-2.0 \\
2.9-2.0 \\
7.5-6.4 \\
7.5-6.4 \\
7.5-6.4 \\
15.5-10.0 \\
15.5-10.0 \\
2.9-2.8 \\
7.5-6.4 \\
7.5-6.4 \\
2.9-2.8 \\
\text { No markers } \\
\text { No markers } \\
\text { No markers } \\
\text { No markers } \\
\text { No markers } \\
\text { No markers } \\
\text { No markers } \\
<2.9 \\
\text { No markers }\end{array}$ & $\begin{array}{l}1.0-0.9 \\
1.6-1.0 \\
1.7-1.6 \\
1.7-1.6 \\
1.8-1.7 \\
1.8-1.7 \\
2.7-2.6 \\
2.7-2.6 \\
6.2-6.0^{*} \\
6.2-6.0^{*} \\
8.6-8.3^{*} \\
? \\
\text { Conflict } \\
2.9-2.8 \\
6.2-6.0^{*} \\
6.2-6.0^{*} \\
2.9-2.8 \\
? \\
5.4-3.7 \\
? \\
5.4-3.7 ? \\
3.7-2.6 \\
? \\
7.3-6.6 \\
2.6-1.6 \\
5.4-2.6\end{array}$ \\
\hline $\begin{array}{l}\text { 146-892D- } \\
\text { 1X, CC } \\
2 \mathrm{X}-1,6-9 \text { to } 2 \mathrm{X}-2,6-8 \\
2 \mathrm{X}, \mathrm{CC} \\
3 \mathrm{X}-1,5-7 \\
3 \mathrm{X}, \mathrm{CC} \\
4 \mathrm{X}-1,29-31 \text { to } 5 \mathrm{X}-1,52-54 \\
5 \mathrm{X}-2,95-97 \text { to } 7 \mathrm{X}-3,74-77 \\
7 \mathrm{X}-4,113-116 \\
7 \mathrm{X}-5,32-34 \\
7 \mathrm{X}-6,21-23 \\
7 \mathrm{X}, \mathrm{CC} \\
8 \mathrm{X}-1,43-45 \\
8 \mathrm{X}-2,57-60 \text { to } 8 \mathrm{X}-3,65-67 \\
8 \mathrm{X}, \mathrm{CC} \text { to } 9 \mathrm{X}-1,33-34 \\
9 \mathrm{X}-2,33-34 \text { to } 9 \mathrm{X}-3,35-36 \\
9 \mathrm{X}-4,34-35 \text { to } 9 \mathrm{X}-5,33-34 \\
9 \mathrm{X}, \mathrm{CC} \\
10 \mathrm{X}-1,34-35 \text { to } 11 \mathrm{X}-1,20-22 \\
11 \mathrm{X}-2,46-48 \\
11 \mathrm{X}, \mathrm{CC} \\
12 \mathrm{X}-2,91-93 \text { to } 12 \mathrm{X}-3,81-83 \\
13 \mathrm{X}-\mathrm{CC}, 13-14 \\
14 \mathrm{X}-1,76-77 \text { to } 15 \mathrm{X}-3,77-79 \\
16 \mathrm{X}-1,37-38 \text { to } 16 \mathrm{X}-3,35-36 \\
16 \mathrm{X}-4,106-108 \\
16 \mathrm{X}-5,53-55\end{array}$ & $\begin{array}{c}8.50 \\
8.56-10.06 \\
18.00 \\
18.05 \\
27.50 \\
27.79-37.52 \\
39.45-57.50 \\
59.39 \\
60.08 \\
61.24 \\
61.70 \\
62.13 \\
63.57-65.15 \\
69.30-6.63 \\
71.13-71.96 \\
72.93-73.85 \\
77.60 \\
100.34-109.07 \\
111.46 \\
119.00 \\
121.41-122.81 \\
128.63 \\
138.76-151.27 \\
157.37-159.86 \\
162.09 \\
163.06\end{array}$ & $\begin{array}{c}1.6-0.3 \\
2.6-1.6 \\
2.6-1.6 \\
9.0-8.3 \\
12.8-11.4 \\
6.2-5.7 \\
3.7-2.6 \\
\\
8.3-7.45 \\
3.7-2.6 \\
\text { Barren } \\
2.6-2.0 \\
5.4-3.7 \\
\text { Barren } \\
2.7-1.8 \\
\\
2.7-1.8 \\
6.6-5.4 \\
2.7-1.8 \\
2.0-0.5 \\
7.45-6.6 \\
7.2-6.6 ?\end{array}$ & $\begin{array}{l}1.2-0.9 \\
1.2-0.9 \\
2.0-1.0 \\
2.0-1.0 \\
2.0-1.0 \\
2.9-2.0 \\
15.5-10.0 \\
15.5-10.0 \\
15.5-10.0 \\
2.9-2.8 \\
2.9-2.8 \\
2.9-2.8 \\
2.9-2.8 \\
\text { Barren } \\
\text { Barren } \\
\text { Barren } \\
2.9-2.8 \\
\text { Barren? } \\
<2.9-2.8 \\
<2.9-2.8 \\
\text { Barren } \\
\text { Barren } \\
\text { Barren } \\
\text { Barren } \\
\text { Barren } \\
\text { Barren }\end{array}$ & $\begin{array}{c}1.2-0.9 \\
1.2-0.9 \\
2.0-1.6 \\
2.0-1.6 \\
2.0-1.6 \\
2.6-2.0 \\
\text { Conflict } \\
12.8-11.4 \\
\text { Conflict } \\
2.9-2.8 \\
2.9-2.8 \\
8.3-7.45 \\
2.9-2.8 \\
? \\
2.6-2.0 \\
5.4-3.7 \\
2.9-2.8 \\
\\
2.7-1.8 \\
2.7-1.8 \\
2.7-1.8 \\
6.6-5.4 \\
2.7-1.8 \\
2.0-0.5 \\
7.45-6.6 \\
7.2-6.6 ?\end{array}$ \\
\hline $\begin{array}{l}146-892 \mathrm{E} \\
1 \mathrm{X}-2,38-40 \\
3 \mathrm{H}-3,54-56 \text { to } 3 \mathrm{H}-4,47-49 \\
3 \mathrm{H}-6,20-22 \\
4 \mathrm{H}-1,104-106\end{array}$ & $\begin{array}{c}0.64 \\
35.70-37.11 \\
39.83 \\
43.54\end{array}$ & $\begin{array}{l}2.7-2.0 \\
9.0-8.3 \\
7.3-1.8 \\
9.0-8.3\end{array}$ & $\begin{array}{l}\text { Barren } \\
\text { Barren } \\
\text { Barren } \\
\text { Barren }\end{array}$ & $\begin{array}{l}2.7-0 \\
9.0-8.3 \\
7.3-1.8 \\
9.0-8.3\end{array}$ \\
\hline
\end{tabular}

Notes: * = diatom age favored over radiolarian; ? = age uncertain.

cies, however, do not affect the position of the stratigraphic reversals observed. Radiolarian ages in the Miocene are generally 1-2 m.y. older than the diatom ages. These differences are sometimes reconcilable. For example, diatom ages of 6.2-6.0 Ma, found in Cores 146$892 \mathrm{~A}-4 \mathrm{X}$ and $8 \mathrm{X}$, have a corresponding radiolarian age of 7.5-6.4 $\mathrm{Ma}$. The radiolarian age constraint of $6.4 \mathrm{Ma}$ is based on using an age of $6.4 \mathrm{Ma}$ for the last occurrence of Stichocorys peregrina (Caulet, this volume). However, the last occurrence of $S$. peregrina is diachronous in the North Pacific and varies between 5.0 and 6.4 Ma in the sites drilled during Leg 145 (Morley and Nigrini, in press), and the last occurrence of $S$. peregrina is reported at $2.6 \mathrm{Ma}$ in the tropics (Moore, 1995). It is possible that $S$. peregrina has its last occurrence later than 6.4 Ma near Oregon, thus reconciling diatom and radiolarian ages for these intervals. A younger age for the last occurrence of $S$. peregrina at Site 892 is also supported by the observations of
Weather et al. (1981) and Kling (1973) who reported a Pliocene age for this event in California sequences (Weather et al., 1981) and in marine sediments off California (Kling, 1973).

On the other hand, some differences between diatom ages and radiolarian ages are still unresolved. In particular, in Cores 146-892A$6 \mathrm{X}$ to $7 \mathrm{X}$ and Cores $146-892 \mathrm{D}-5 \mathrm{X}$ to $7 \mathrm{X}$, late Miocene diatom ages (9.0-8.3 Ma) conflict with middle Miocene radiolarian ages (15.5-10 $\mathrm{Ma}$ ). The upper constraint for the radiolarian ages is the last occurrence of Cyrtocapsella japonica at $10.0 \mathrm{Ma}$, which is isochronous in the North Pacific, according to Morley and Nigrini (in press). Cyrtocapsella japonica is common in the samples studied from Site 892, supporting a $10 \mathrm{Ma}$ minimum age for those samples. The diatom assemblages in the same samples are well preserved, abundant, and clearly characteristic of the late Miocene Denticulopsis hustedtii Zone based on the occurrence of common Denticulopsis hustedtii 


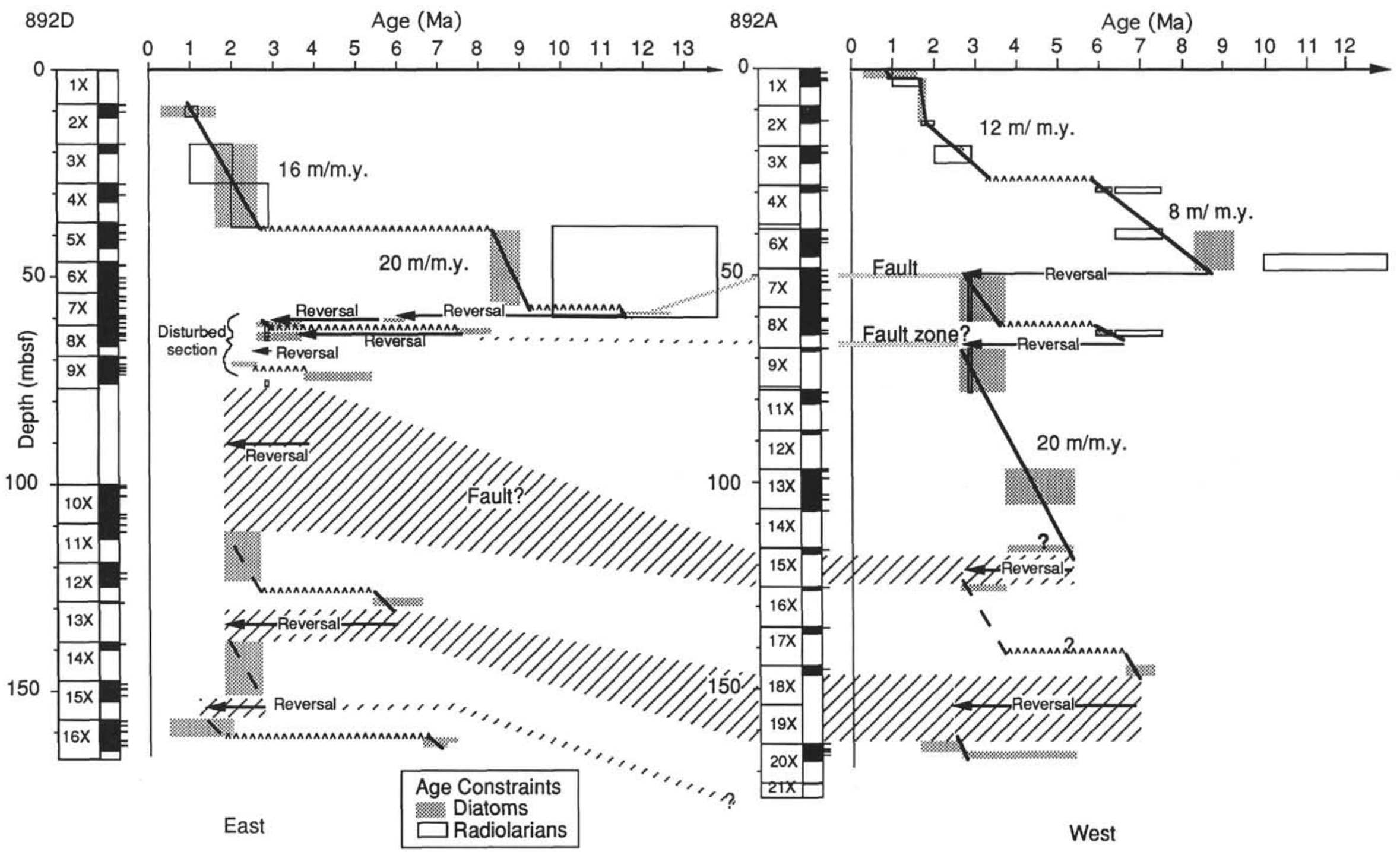

Figure 1. Age vs. depth plots of Holes 892D and 892A, based on diatom and radiolarian biostratigraphy and tentative correlation between the two holes. Unconformities (wavy lines) and stratigraphic reversals are shown. Black = recovered sediments; tick marks $=$ samples studied. 
(last common occurrence $8.4 \mathrm{Ma}$ ), common D. katayamae (first occurrence 9.4-9.1 Ma), as well as the associated species Rouxia californica and Thalassionema schraderi (see Fourtanier, this volume). One could argue that $C$. japonica is reworked in this interval; howev$\mathrm{er}$, the diatom study does not show evidence of reworking from the middle Miocene.

\section{Correlation Between Hole 892A and 892D and Significance of the Reversals}

Differences in the biostratigraphy of Holes 892A and 892D (Table 3) can be in part explained by the high level of complexity of the stratigraphy and a relatively poor recovery. In addition, because strata and faults are not horizontal, and folds possibly occur at Site 892 (Shipboard Scientific Party, 1994), the horizontal seafloor distance of 20 meters between Hole 892A (to the west) and Hole 892D (to the east) accounts for additional differences between the two holes. However, a large number of similarities are observed between Holes $892 \mathrm{~A}$ and $892 \mathrm{D}$, and a tentative correlation is proposed in Figure 1.

Correlation is clear between the top 50 meters of Hole $892 \mathrm{~A}$ and the top 60 meters of Hole 892D where a sequence of Quaternary and Pliocene sediments is followed by Miocene sediments. The middle Miocene interval at $59 \mathrm{mbsf}$ in Hole $892 \mathrm{D}$ is probably correlative with the middle Miocene interval identified by radiolarians at $\sim 45$ mbsf in Hole 892A. The reversals at $48.99-50.10 \mathrm{mbsf}(892 \mathrm{~A})$ and 59.39-60.08 mbsf (892D) correlate (Fig. 1) and confirm the presence of a fault as suggested by changes in dip bedding and by fractures identified by the FMS $\log$ at about 52 mbsf in Hole 892C (Shipboard Scientific Party, 1994). There is also a reversal between $37.11 \mathrm{mbsf}$ and 39.83 mbsf in Hole 892E.

In Hole 892A, there is another reversal between 64.70 and 67.92 mbsf, where uppermost Miocene sediments overlie upper Pliocene sediments. In Hole 892D, reversals at similar depths are also observed; however, the situation is different, as three reversals are present: 60.08-61.24 mbsf, 62.13-63.57 mbsf, and 65.15-71.13 mbsf. This section of Hole 892D is greatly disturbed in terms of diatom biostratigraphy and may correspond to a fault zone. Additional evidence for a fault zone is suggested by the occurrence of shear bands and stratal disruption between 62.5 and 67 mbsf (Hole 892A) and by a temperature anomaly at $67.5 \mathrm{mbsf}$ (Shipboard Scientific Party, 1994). The bottom-simulating reflector (BSR) is located just a few meters below ( 71 mbsf). Downhole logs and a vertical seismic profile have established that the BSR is caused by free gas below about 71 mbsf (Leg 146 Shipboard Scientific Party, 1993).

Sediments in the middle part of the section cored at Site 892 are mostly Pliocene in age. In Hole 892A, a reversal is observed between 116.42 mbsf (early Pliocene) and $125.64 \mathrm{mbsf}$ (late Pliocene) and may correlate with a reversal in Hole $892 \mathrm{D}$ between $73.85 \mathrm{mbsf}$ and 111.46 mbsf. A fault zone was recognized by the shipboard sedimentologists between Cores 146-892A-15X and 18X, based on observation of stratal disruption and shear bands. It was speculated that Core 146-892A-14X (106.5-116 mbsf) may represent the active fault zone and that the deeper cores (146-892A-15X to $18 \mathrm{X})$ may be earlierformed fabrics (Shipboard Scientific Party, 1994).

In the lower part of Site 892, Cores 146-892A-16X to 18X appear to correlate with Cores 146-892D-11X to $13 \mathrm{X}$, as they both represent a sequence of upper Pliocene sediments overlying uppermost $\mathrm{Mi}$ ocene sediments. We also propose the correlation of the reversal at 145.45-163.69 mbsf in Hole 892A with the reversal at 128.63$138.76 \mathrm{mbsf}$ in Hole 892D, where uppermost Miocene sediments overlie uppermost Pliocene sediments. Another reversal is also observed in Hole 892D between 151.27 and $157.57 \mathrm{mbsf}$ and has no counterpart in Hole 892A. Presumably, the equivalent of this reversal lies below the section cored at Hole 892A. These lower reversals could be explained by the presence of faults; however, folding could also be involved. For example, the section in Hole 892D between $128.63 \mathrm{mbsf}$ and $159.86 \mathrm{mbsf}$, where uppermost Miocene sediments are followed downhole by uppermost Pliocene and Quaternary sediments, could be overturned (i.e., upside down) due to folding.

\section{Sedimentation (Sediment Accumulation Rates, Hiatuses)}

We estimate sediment accumulation rates averaging 12-20 m/ m.y. for the Pliocene and Quaternary and $8-20 \mathrm{~m} / \mathrm{m}$.y. for the late Miocene (see Fig. 1). However, we feel that we cannot provide accurate sediment accumulation rates at Site 892 because: (1) this is a very tectonically-disturbed section, with repeated sequences and missing intervals; (2) bedding is not horizontal and dipping varies; and (3) recovery is not sufficient to allow identification of small (less than 1 m.y.) hiatuses.

The sediments at Site 892 vary in age between late Pleistocene and middle Miocene. All ages are represented except for two intervals in the late Miocene. Using diatom biostratigraphy, the ages of these intervals are 6.2-7.45 Ma and 9.0-11.4 Ma. Interestingly, these same intervals are missing in the nearby DSDP Site 173 (Barron and Keller, 1983). These intervals of missing time correspond to two widely recognized hiatuses in the World Ocean, the Neogene hiatuses NH6 and NH4, respectively (Keller and Barron, 1987).

\section{CONCLUSIONS}

The diatom and radiolarian biostratigraphies are compiled for Site 892 , demonstrating that sediments range in age from the middle Miocene to the late Quaternary. The position of several reversals, where older sediments occur above younger sediments, have been documented within the section cored. There are many different ways of interpreting these reversals, as they can be the results of (1) reverse faults, (2) displaced allochthonous elements within an otherwise continuous section, (3) folds that would create alternating normal and upside-down sections, or (4) a combination of all, or some, of the above. Similarly, the unconformities observed in Site 892 (younger sediment sitting on older sediments with time missing between) can be interpreted as (1) hiatuses, (2) normal faults, and/or (3) displaced allochthonous elements within an otherwise continuous section. The time intervals $6.2-7.5 \mathrm{Ma}$ and $9.0-11.4 \mathrm{Ma}$, which are not represented in any of the recovered sediments, however, do correspond to widely recognized deep-sea hiatuses NH6 and NH4 in the world's oceans. Further studies of sedimentary fabric and structural relationships, as well as consideration of the general setting of Site 892 and its seismic stratigraphy, are necessary to accurately interpret the significance of the reversals and unconformities observed.

\section{ACKNOWLEDGMENTS}

We are grateful to John Barron, Catherine Nigrini, and Lloyd Burckle for their helpful reviews. E.F. was in part supported by USSSP (no. 146-20775b) and J.-P.C. received support from INSU (Soutient à ODP France \# 9339 10).

\section{REFERENCES}

Barron, J.A., 1992a. Neogene diatom datum levels in the equatorial and North Pacific. In Saito, T., and Ishizaki, K. (Eds.), The Centenary of Japanese Micropaleontology: Tokyo (Terra Scientific), 413-425.

Barron, J.A., 1992b. Paleoceanographic and tectonic controls on the Pliocene diatom record of California. In Tsuchi, R., and Ingle, J.C., Jr. (Eds.), Pacific Neogene: Environment, Evolution, and Events: Tokyo (Tokyo Univ. Press), 25-41.

Barron, J.A., and Gladenkov, A.Y., in press. Early Miocene to Pleistocene diatom stratigraphy of Leg 145. In Rea, D.K., Basov, I.A., Scholl, D.W., and Allan, J.F. (Eds.), Proc. ODP, Sci. Results, 145: College Station, TX (Ocean Drilling Program). 
Barron, J.A., and Keller, G., 1983. Paleotemperature oscillations in the middle and late Miocene of the northeastern Pacific. Micropaleontology, 29:150-181.

Cande, S.C., and Kent, D.V., 1992. A new geomagnetic polarity time scale for the Late Cretaceous and Cenozoic. J. Geophys. Res., 97:1391713951.

Keller, G., and Barron, J.A., 1987. Paleodepth distribution of Neogene deepsea hiatuses. Paleoceanography, 2:697-713.

Kling, S.A., 1973. Radiolaria from the eastern North Pacific, Deep Sea Drilling Project, Leg 18. In Kulm, L.D., von Huene, R., et al., Init. Repts. DSDP, 18: Washington (U.S. Govt. Printing Office), 617-671.

Koizumi, I., 1992. Diatom biostratigraphy of the Japan Sea: Leg 127. In Pisciotto, K.A., Ingle, J.C., Jr., von Breymann, M.T., Barron, J., et al., Proc. ODP, Sci. Results, 127/128 (Pt. 1): College Station, TX (Ocean Drilling Program), 249-289.

Koizumi, I., and Tanimura, Y., 1985. Neogene diatom biostratigraphy of the middle latitude western North Pacific, Deep Sea Drilling Project Leg 86. In Heath, G.R., Burckle, L.H., et al., Init. Repts. DSDP, 86: Washington (U.S. Govt. Printing Office), 269-300.

Moore, T.C., Jr., 1995. Radiolarian stratigraphy, ODP Leg 138. In Pisias, N.G., Meyer, L.A., Janecek, T.R., Palmer-Julson, A., and van Andel, T.H. (Eds.), Proc. ODP, Sci. Results, 138: College Station, TX (Ocean Drilling Program), 191-232.
Morley, J.J., and Nigrini, C., in press. Miocene to Pleistocene radiolarian biostratigraphy of North Pacific Sites 881, 884, 885, 886, and 887. In Rea, D.K., Basov, I.A., Scholl, D.W., and Allan, J.F. (Eds.), Proc. ODP, Sci. Results, 145: College Station, TX (Ocean Drilling Program).

Leg 146 Shipboard Scientific Party, 1993. ODP Leg 146 examines fluid flow in Cascadia Margin. Eos, 74:345-346.

Shipboard Scientific Party, 1994. Site 892. In Westbrook, G.K., Carson, B., Musgrave, R.J., et al., Proc. ODP, Init. Repts., 146 (Pt. 1): College Station, TX (Ocean Drilling Program), 301-378.

Weather, F.M., Casey, R.E., and Perez, A.M., 1981. Stratigraphic and paleoceanographic significance of early Pliocene to middle Miocene radiolarian assemblages from Northern to Baja California. In Garrison, G., and Douglas, R.E. (Eds.), The Monterey Formation and Related Siliceous Rocks of California. Soc. Econ. Paleontol. Mineral., Pacific Sect., 71-86.

\section{Date of initial receipt: 5 December 1994 \\ Date of acceptance: 30 May 1995}

Ms 146SR-242 